\title{
The Directions of Formal Expression in Latvian Contemporary Architecture in the Context of the Synthesis of the Arts
}

\author{
Ilze Rukmane-Poča, Linda Leitāne-Šmīdberga, Riga Technical University
}

\begin{abstract}
Different types of formal expression can be found in the modern architecture of the 21 st century - in publications, internet resources and in the generalizations of critics. In the context of the synthesis of arts the styles of sculptural architecture and surface architecture are noteworthy. Characteristics of this synthesis are also noticeable in kinetic architecture where the styles of surface kinetic architecture and sculptural kinetic architecture are distinguished. The genesis of images of buildings constructed in these styles is the result of the synthesis of arts; it reflects the development of historical styles as well as the ways of formal expression and their influences in the end of the 20th century and in the 21st century. This paper provides an analysis of constructed objects and proposals put forth in architectural competitions in Latvia's 21 st century modern architecture.
\end{abstract}

Keywords - Architecture of 21st century, architecture history, synthesis of arts, surface architecture, sculptural architecture, kinetic architecture, architectural competitions.

After the last defined style [1] - the postmodern period - the architecture of today, is in a state of formation and formulation. Amidst this process different styles of formal expression emerge, emphasizing the artistic quality of the environment, energetic efficiency as well as the long-term durability of buildings. The styles of modern minimalism, High Tech, biomorphic or bionic architecture, neo-postmodernism and deconstructionism are still highly relevant today. These features are visible in contemporary 21 st century manner in the synthesis of a number of stylistic trends and impacts in a single object thus framing the entrance to the contemporary "modernist" period, which will gain its real style name apparently only in future. A new direction "art architecture" has become popular, which is the new architectural identity of the 21 st century. Art architecture reflects the fact that the buildings follow art, but the art determines the society. There are several public and interest groups created that follow the slogan Art Architecture. Usually they are interdisciplinary creative collectives that in their projects are looking for creativity, innovation and experiments [2]. Architect and publicist A. Zvirgzdiņš in his article "Architecture as Art" looking on the interaction of architecture and art defined the sphere of "architecture as art". His argument is held on the grounds that "starchitects" have created an iconic architectural base and on the studies of the book "The Iconic Building - The Power of the Enigma" [1], [2], [3], [4] published in 2005 by architectural critic Charles Jencks. The term "Art Architecture" is very broad. It covers a number of directions of contemporary architectural formal expression that developed in the 21 st century due to the involvement of various visual arts in architecture.

Various means of formal expression and characteristics in sculptural and surface architecture - in the synthesis of arts can already be defined. They are summarized in the scheme (Fig. 1) as an addition to the scheme of historical styles developed by Professor J. Krastinšs [5], [1].

Alongside the world trends, many such means and characteristics can be discerned in Latvian contemporary architecture. The two leading styles with regard to the synthesis of arts are

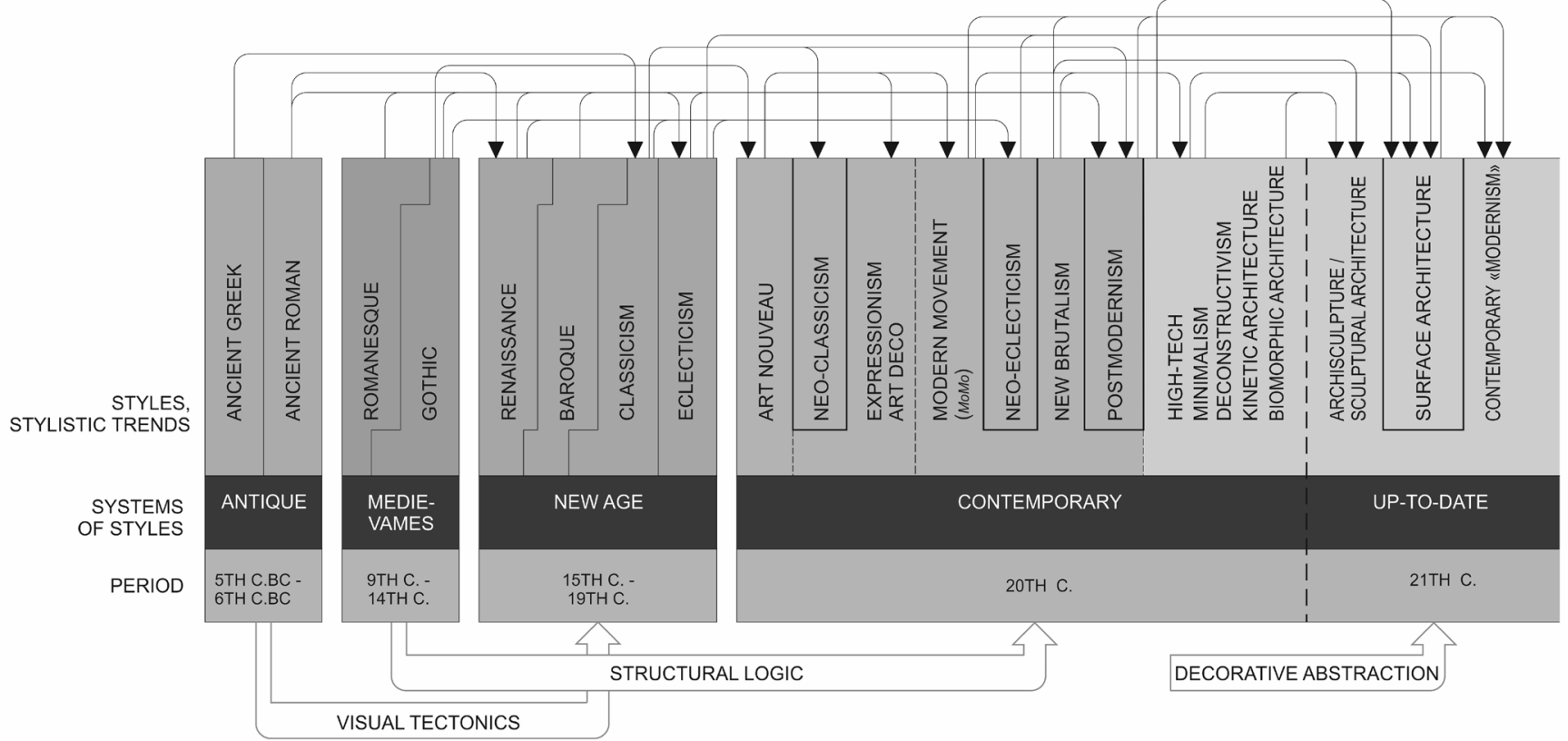

Fig. 1. Architectural styles and style system development scheme. 


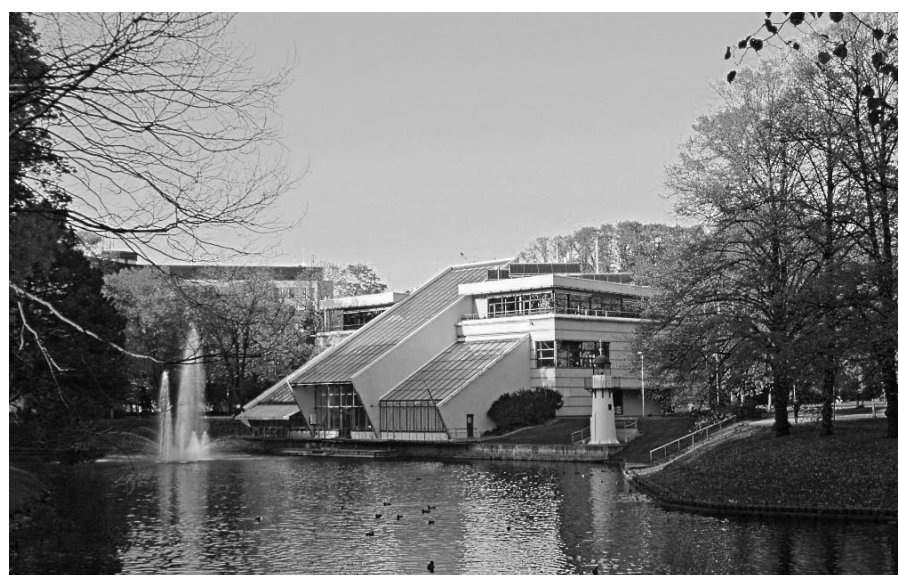

Fig. 2. Riga. Administrative building at 1 Kronvalda Boulevard. "NAMS", architect M. Malahovskis, 2000. Photo - J. Krastiņš.

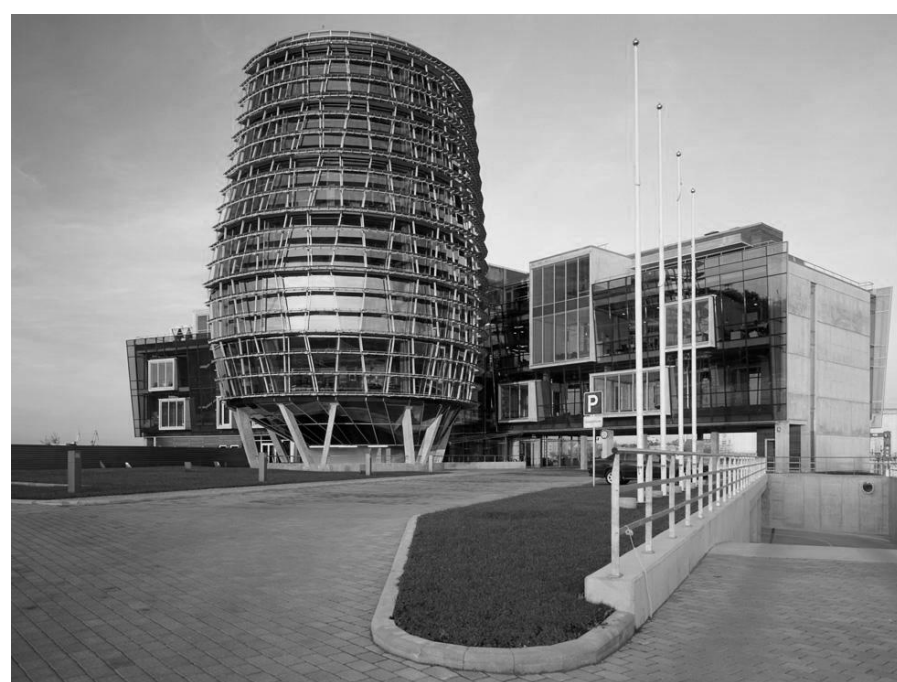

Fig. 4. Rīga. Office building in Ķīpsala, 15 Matrožu Street. "Arhitektonika", 2004-2007 [9]

sculptural architecture or archisculpture and surface architecture. The merging of arts is also noticeable in kinetic architecture where a distinction of surface kinetic architecture and sculptural kinetic architecture should be made. The most vivid display of the synthesis of arts in Latvia can be found in the architecture of public buildings. Alongside public buildings, the synthesis is present in the forms and façades of residential buildings as well, as an inseparable instrument in the forming of a modern, quality city space.

Sculptural architecture or archisculpture [6] is a style in which a building's primary value is placed in its sculptural image. Its origins are to be found in deconstructionism, organic and bionic architecture and other styles. These styles are more widespread elsewhere in the world. In Latvia only a few of the designed buildings have been constructed in the style of deconstructionism. They were constructed in the end of the 20th century: Administrative building at 1 Kronvalda Boulevard, Automobile centre at 1 Zemzaru Street (Fig. 2), (Fig. 3).

In deconstructionism tectonic architectural elements are deformed in order to achieve a sculptural, dynamic image. In sculptural architecture the construction of the object is primarily

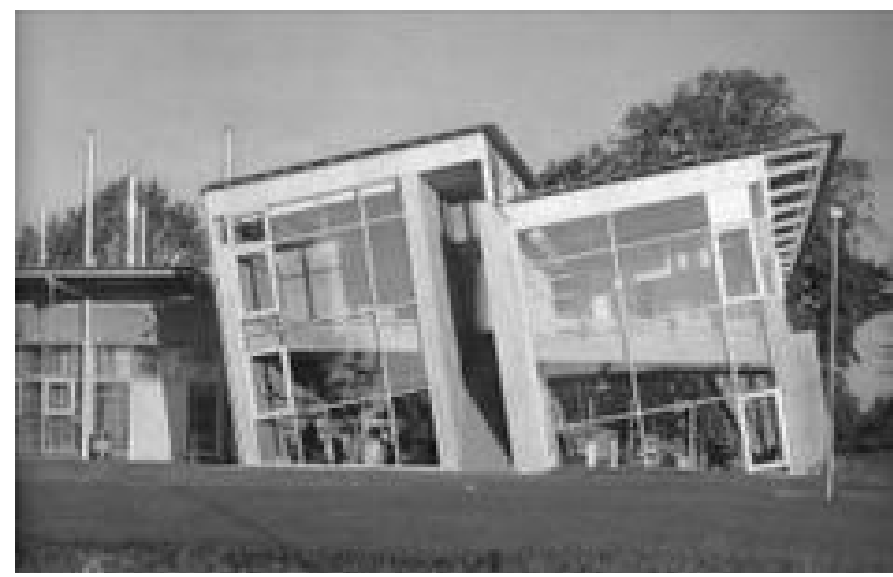

Fig. 3. Mārupe. Automobile centre at 1 Zemzaru Street. R. Beihlers (Germany), 2001. Photo - J. Krastiņš [5].

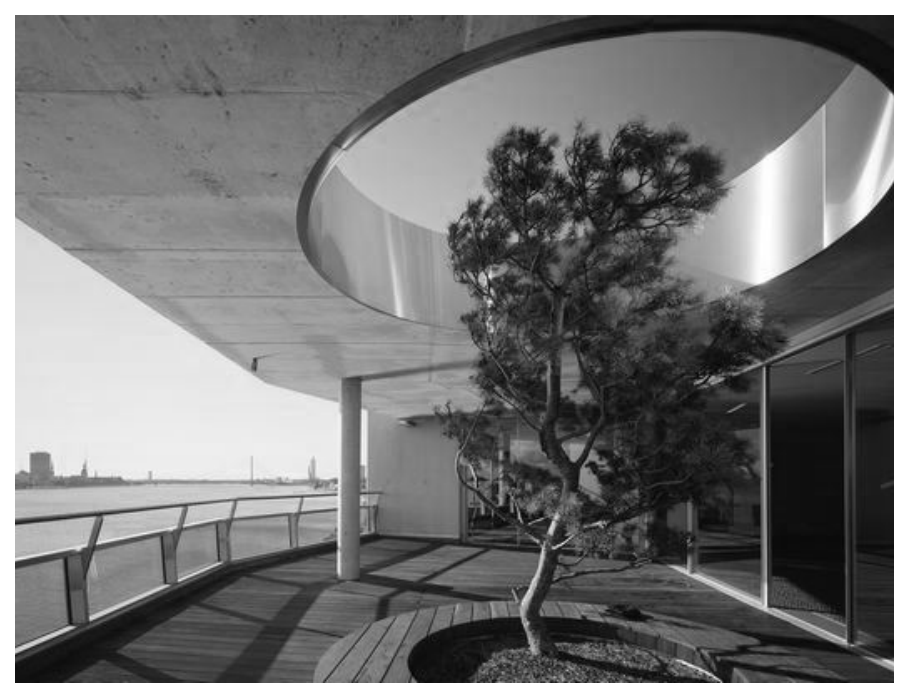

Fig. 5. Rīga. Office building in Ķīpsala, 15 Matrožu Street. "Arhitektonika”, 2004-2007 [9].

subject to the idea of its sculptural image. In sculptural architecture both the interior and exterior are subject to buildingsculpture rules. Luis Sullivan idea "form ever follows function" was replaced by the idea of sculpturalism "function follows form" [7]. In sculptural architecture form is the primary tool for the architect and the other components are subordinate [7]. This style results in impressive and attractive objects, leaving neither the adherents of sculptural architecture nor its opponents indifferent. Most of the objects designed in this style remain unconstructed; however, thanks to the advances in new materials and technologies, the style has undergone rapid development since 1990. The years $1970-1980$ was a period of transition. "Paper architecture was producing new ideas and principles of architecture and ceased to be just formal studies in composition. The conceptual leap from 'architecture and art' to 'architecture as art' did not land in a vacuum" [8]. Synthesis of arts in contemporary architecture is found in theatrical, sculptural, often complex buildings by architects such as D. Libeskind, F. Gehry, E. O. Mosa, Z. Hadid and others. In Latvia this style is present in the work of I. Lazdiñš in the administrative building of Corporation RBS SKALS constructed in Ķipssala, 15 Matrožu Street 


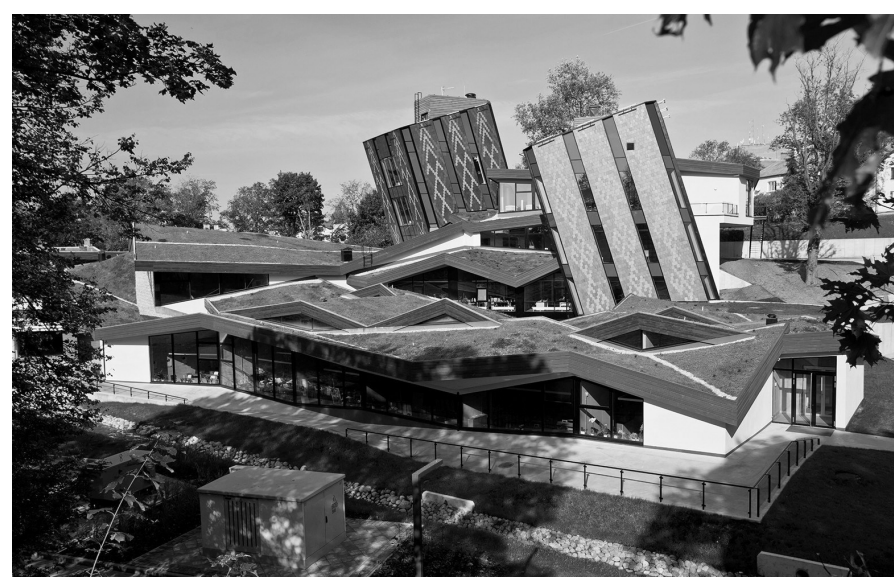

Fig. 6. Rēzekne. Centre of creative industries "Zeimuls. "SAALS”, 2012 [10]”.

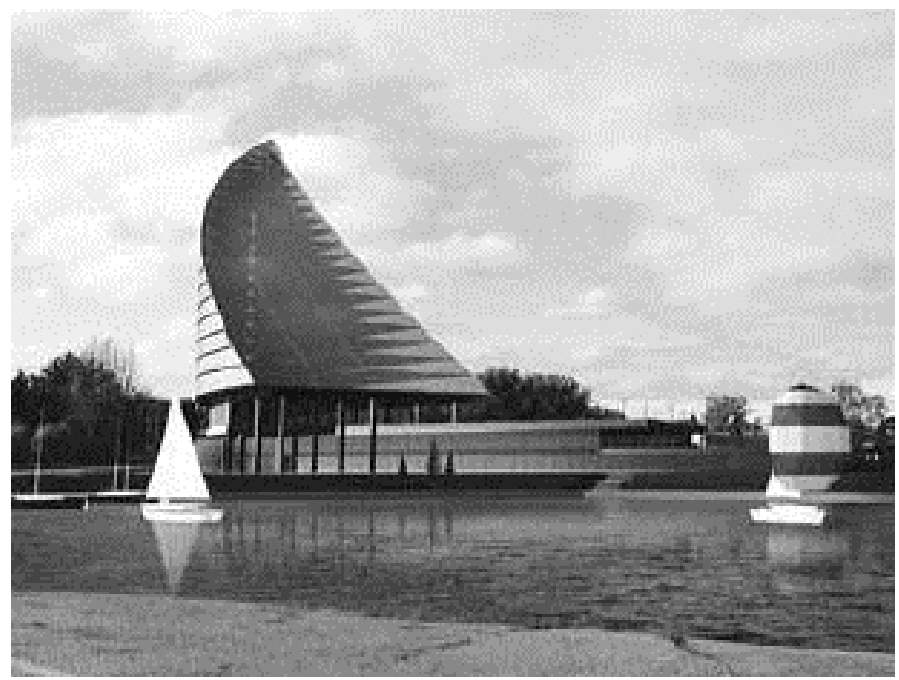

Fig. 8. Rīga. "Saules akmens". Multifunctional office building. Competition proposal. "Zenico projekts", TECTUM, 2001 [12].

(competition held in 2003, time of construction 2004-2007), the annex of the Latvian Academy of Arts (constructed in 2013, author - architect studio SZK); in the competition projects 2010 for the building of Latvian National Museum of Art; in the projects of architects A. Sīlis, U. Zābers, V. Didrihsons and others (Fig. 4), (Fig. 5).

These buildings are primarily public buildings which express the significance of the building and accentuate the nearby urban environment. In the 21 st century, sacred structures no longer determine the silhouettes of cities and prescribe their only means of recognition, as in the medieval, renaissance and baroque periods. Today this function falls to other public buildings and structures - museums, libraries, concert halls. These objects become each city's symbols and placemarks.

There are a number of internationally recognized examples of sculptural architecture in Latvian contemporary architecture - for example, The National Library of Latvia (construction and realization in 1989-2014, architect Gunnar Birkerts, technical project of architect studio "Ģelzis-Šmits-Arhetips") and the centre of creative industries "Zeimuls" located in Eastern Latvia (2007 competition, construction in 2009-2012, architect

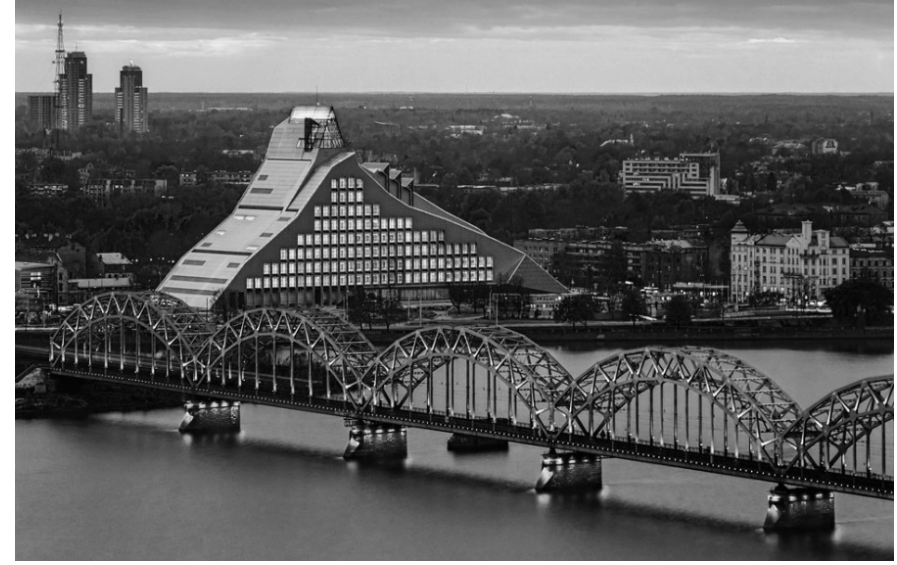

Fig. 7. Rīga. The National Library of Latvia. G. Birkerts, "Ģelzis-Šmits-Arhetips", 2008-2014 [11].

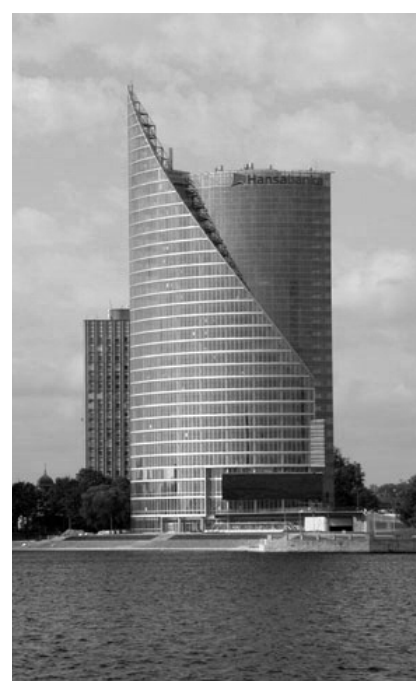

Fig. 9. Rīga. Multifunctional office building. "Zenico projekts", TECTUM, 2004 [13]

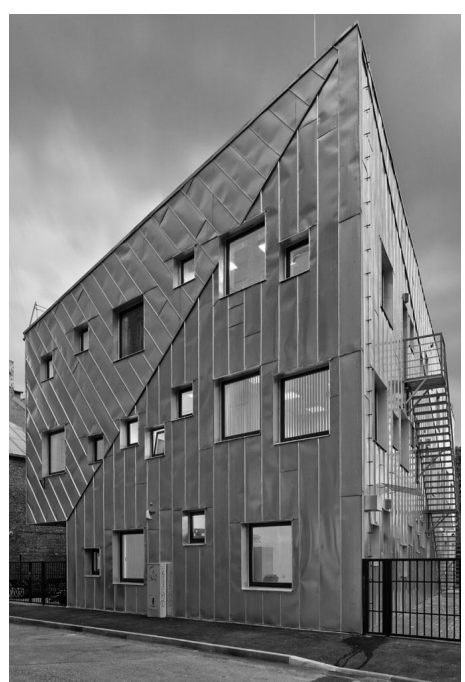

Fig. 10. Rīga. "Diena" care centre for the homeless. "Lejnieku Design Bureau", "8 A.M.", 2009 [14]. studio SAALS) (Fig. 6), (Fig. 7). For the moment Latvian projects have not yet managed to achieve an effect similar to that of Bilbao - when a world-class project becomes a catalyst for economically disadvantaged urban development. The centre of creative industries "Zeimuls" has proven this idea by arranging Rēzekne's mound site and making the issue of the urban environment a socially important issue. R. Kalnina - the author of this work - emphasizes the need for recognition in architecture; the necessity for a conceptual code that unifies form with content - "the louder the idea, the more recognizable the building".

The "Swedbank" administrative high-rise building is one of the first objects constructed in sculptural form in 21st Century Riga. The initial drafts submitted in 2001 placed larger emphasis on the building's image and symbolism, but during the time of construction the object acquired magnitude and is now far from its original intent (Fig. 8), (Fig. 9). A lot of objects constructed in Latvia display features of sculptural architecture in their overall image, such as the "Diena" care centre for the homeless (Fig. 10) and the sports stadium of Majori elementary school (Fig. 11).

The sports stadium of Majori elementary school (Fig. 11) 


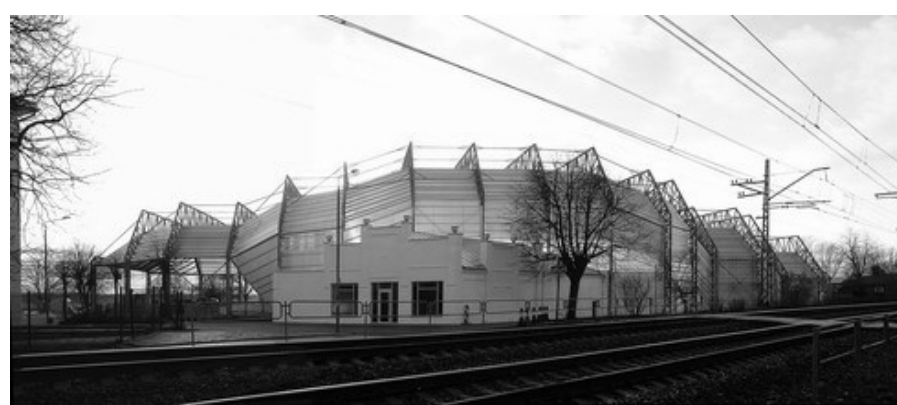

Fig. 11. Jūrmala. Sports stadium of Majori elementary school. Architect studio "Substance", 2008 [18].

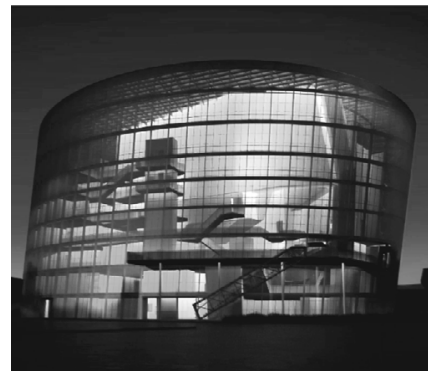

Fig. 12. Liepāja. Multi-functional centre "Lielais Dzintars". "Giencke \& Company", 2015 [19].

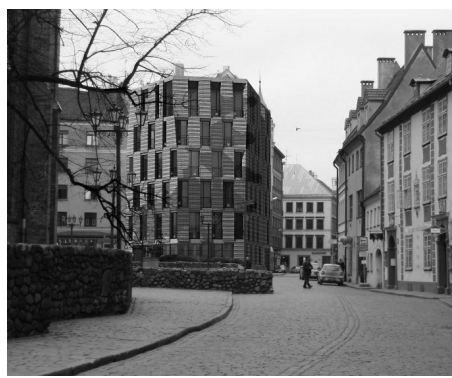

Fig. 13. Rīga. multi-story apartment building at 11 Skārņu Street. "Jaunromāns un Ābele", 2014 [17].

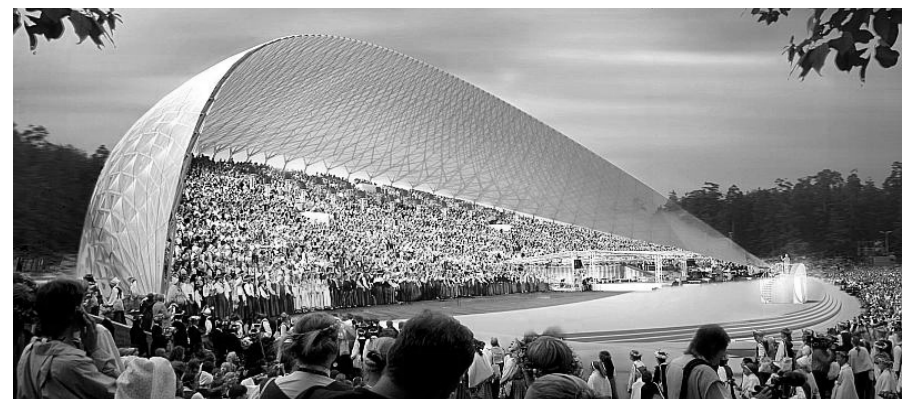

Fig. 14. Rīga. "Song Festival" stage in Mežaparks. Winner of the reconstruction sketch competition. "Mailītis A.I.I.M" and "Jura Pogas birojs", 2007 [20].

received a positive assessment in Latvian Architecture Award 2007, winning a Certificate of Recognition for its tectonic clarity and innovative approach in image construction, in the category for "New buildings - public buildings \& residential apartment buildings". The concert hall "Lielais dzintars" in Liepāja was constructed in the same style (Fig. 12). The Austrian architecture office "Giencke \& Company" won the international competition for invited architects in 2003. Jury member architect Sigvards Grava noted that: "The building should become a city icon" [15]. The large concert hall is intended for 1080 spectators, chamber hall for 200 spectators. The forms of "Lielais dzintars" consist of steel frame. "Exterior walls are translucent orange with self-cleaning tempered double-shell" [16].

A multi-story apartment building in the Centre of Riga at 11 Skārṇu Street (Fig. 13) was created by the architect studio "Jaunromāns un Ābele". The architects created it as a sculptural volume that respects the historical building context. In 2006 an international competition was announced setting high architectural quality criteria. During the project (2012-2015) architects devoted much attention to the culture of detail, implemented both

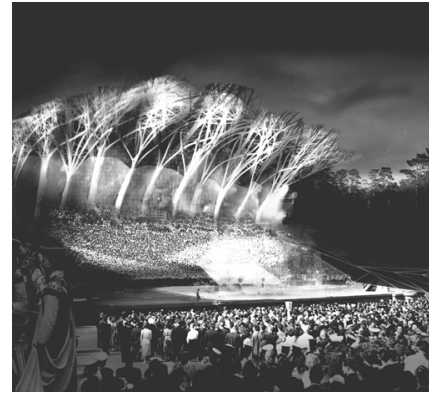

Fig. 15. Rīga. "Song Festival" stage in Mežaparks. Proposal for the reconstruction sketch competition. U. Šēnbergs, 2007 [21].

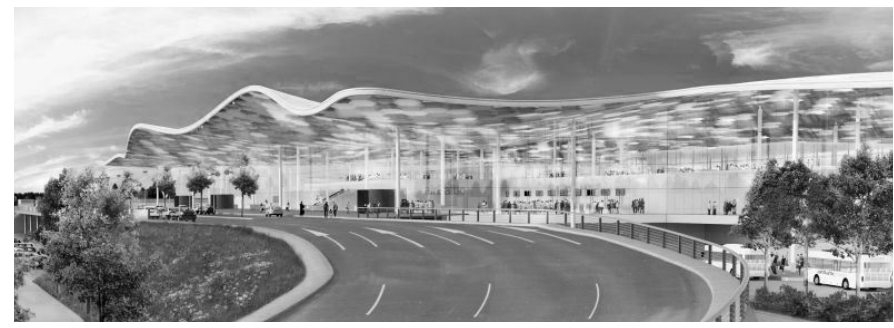

Fig. 17. Rīga. AirBaltic passenger terminal. Winner of the sketch cometition. "Haptic Architects", 2012 [23].

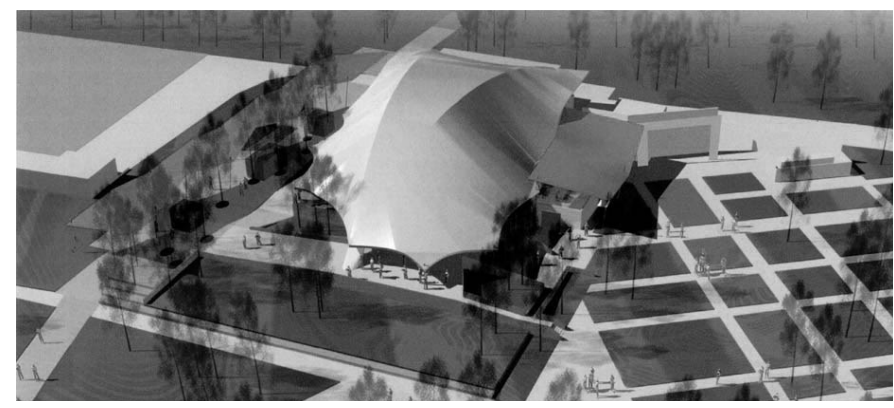

Fig. 18. Liepāja. The proposal for the reconstruction of the open air stage "Pūt Vējiņi”. Competition winner. "Kokin idea", 2011 [24].

through the texture of red brick facade and rhythm of the subject window Old scale. The first floor offers publicly rentable space, the second floor houses office facilities, but the top floors offer exclusive apartments [17].

Several examples of sculptural architecture have remained only as paper architecture. Such examples are submissions to the international competition for the rebuilding of the "Song Festival" stage in Mežaparks in 2007 - the winning project by "Mailītis A.I.I.M." and "Architects Bureau of J. Poga" (Fig. 14), and the entry project by Ugis Šēnbergs (Fig. 15). Latvia pavilion at the international exhibition "EXPO Milano 2015" by architects' bureau "Made arhitekti" was not built (Fig. 16). The pavilion was intended in the form of oak tree. The competition entry for the reconstruction of AirBaltic passenger terminal in 2012 was designed with a sculptural roof - reminiscent of the Latvian landscape (Fig. 17). The entry project to the competition 2011 for the reconstruction of the open air stage "Pūt Vejjinin" in Liepāja and its surrounding grounds was designed as spatially expressive seasonal object (Fig. 18). In 2006 international competition for the construction of Riga 

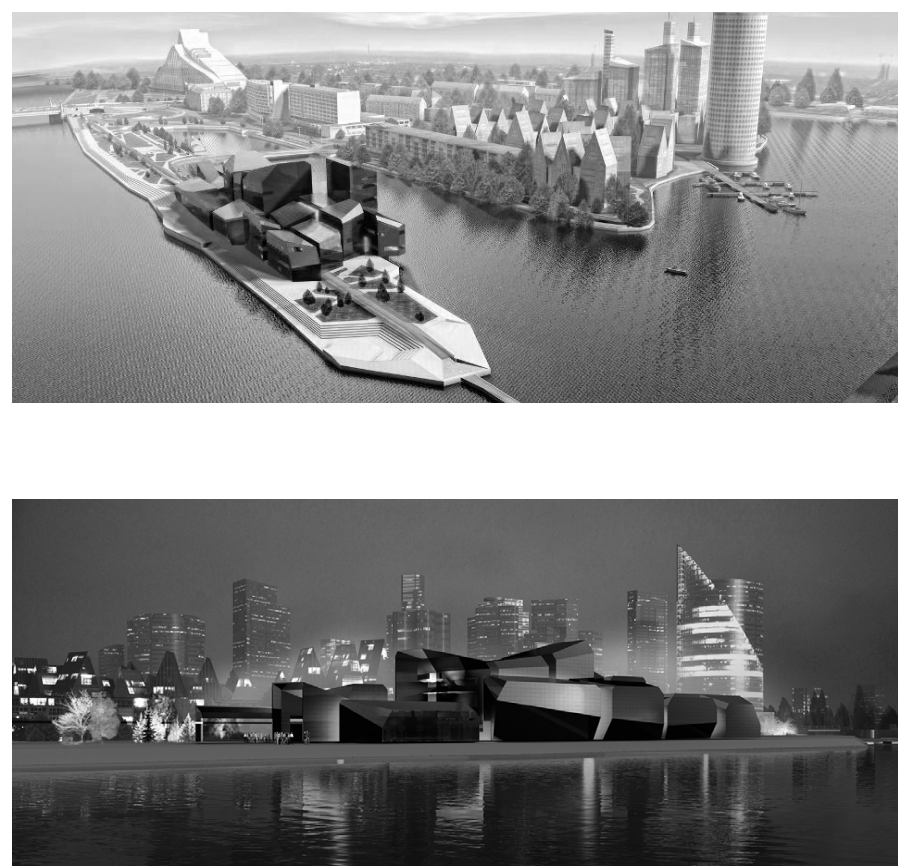

Fig. 19. Latvia. Riga Concert Hall. Competition winner. “AB.SZK”, 2006 [25].

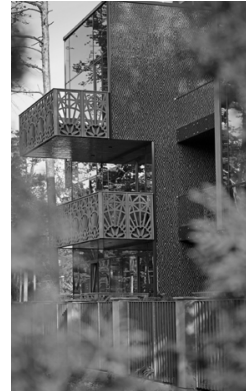

Fig. 20. Jūrmala. Apartment building ma Street. Competition winner. "NRJA", 2012 [27] at 32 Dzintaru

Street. "SZK
2013 [26].

Concert Hall the building's visual image interpreted the characteristic scale of Old Riga roof landscape (Fig. 19).

An important feature of surface architecture is the outer graphic, pictorial or sculptural image of a building's surface envelope. Often the load-bearing elements of the building are completely separated from the decorative structure which is the "skin" of the building. In the 21 st century, one can distinguish several surface architecture styles: ornamental architecture, pictorial surface architecture, ornamental sculptural surface architecture, textile architecture and kinetic surface architecture.

Ornamental architecture is a formal style in surface architecture where special attention is paid to the graphic, ornamental finish of a façade. The surfaces of buildings in these styles are created using visual means - graphically expressive and polychrome prints, cut out patterns, stained glass windows. Digital technologies, 3D scanners, laser technologies and other technical means allow for the realization of practically any idea. In Latvia, this style is used in façade details, creating dec-

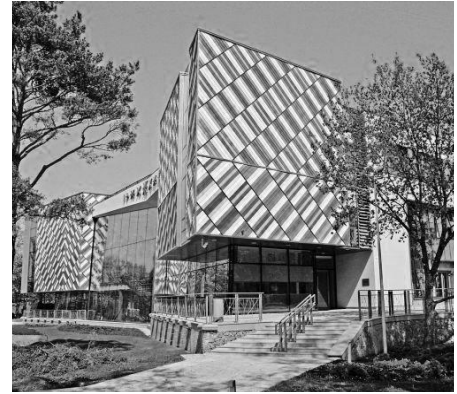

Fig. 22. Ādaži. Culture education centre. D. Rampāne. 2009 - 2010 [28].

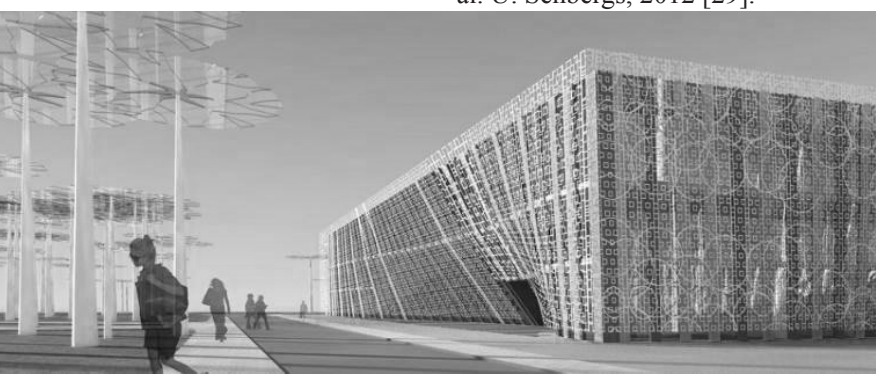

Fig. 24. Jūrmala. "Community Centre” in Jūrmala. Competition proposal. 2009. Unbuilt. Authors: "Balta istaba" - Roberts Riekstinš, Ilze Rukmane-Poča, Aija Morica, Elīna Jakovele, Ieva Māksena, Sallija Bitīte, piedalījās Reinis Prēdelis, Elza Režā, Olafs Barons [30].

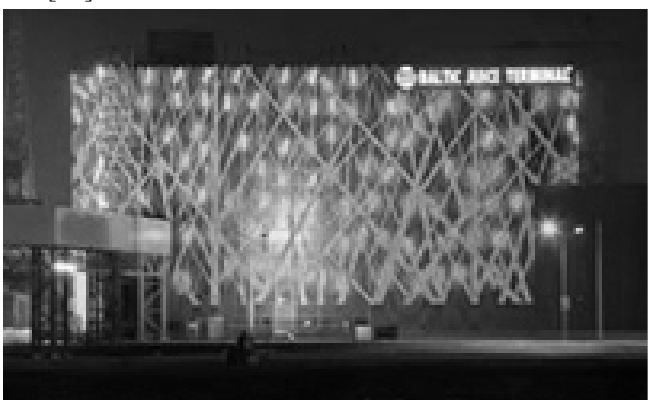

Fig. 25. Ventspils. Industrial building at 3/5 Dzintaru Street. "AKA", 2006 2007 [31].

orative pattern shaped rails (Fig. 20). Ornamental façade panels are used in the competition entry for office and apartment building at 2 Kalnciema Street (Fig. 21). Most of the objects created in the period of economic crisis in Latvia (2008-2013) were not constructed (Fig. 23), (Fig. 24).

One of the already constructed examples of ornamental architecture is the new culture education centre in Âdaži (Fig. 21). Painted composite plates and cement cladding panels in various shades of wood texture were used in the decoration of the façade. The traditional quilt motif as well as the Latvian sign symbols and patterns weave throughout the building and it's interior.

The competition entry for the construction of the "Community Centre" in Jūrmala was intended as a monolithic structure. One of the facades bends at the first floor level creating recesses at the entrance of the building (Fig. 24). An industrial building has been constructed in a similar manner in Ventspils, 3/5 Dzintaru Street; authors - architects bureau "AKA" (Fig. 25). 

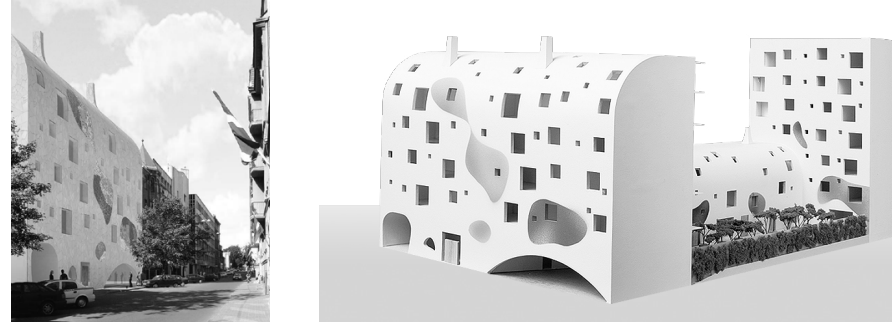

Fig. 26. Rīga. Apartment building at 17 Skolas Street 17. Competition winner "JKMM", 2006 [32].

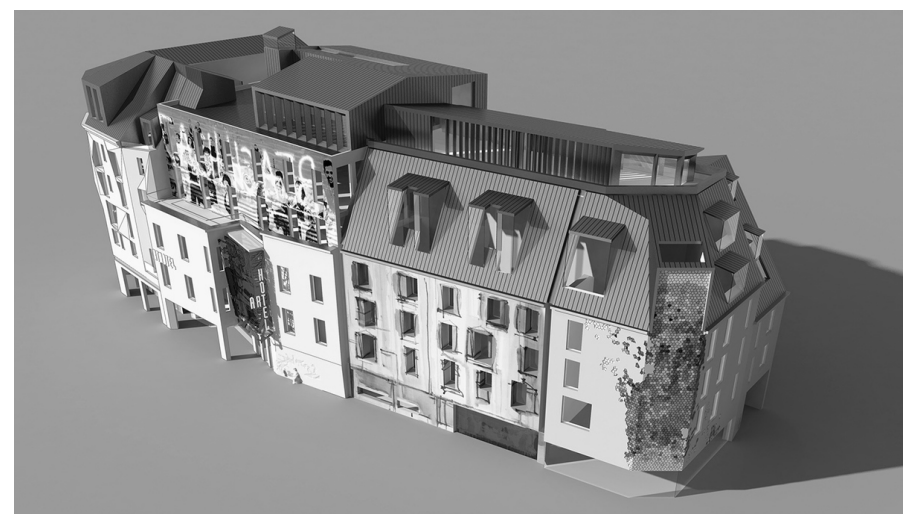

Fig. 27. Rīga. 12 Audēju Street. Proposal for a hotel. A. Sīlis, I. Miķelsone. Artist - K. Ģelzis,. 2008 [33].
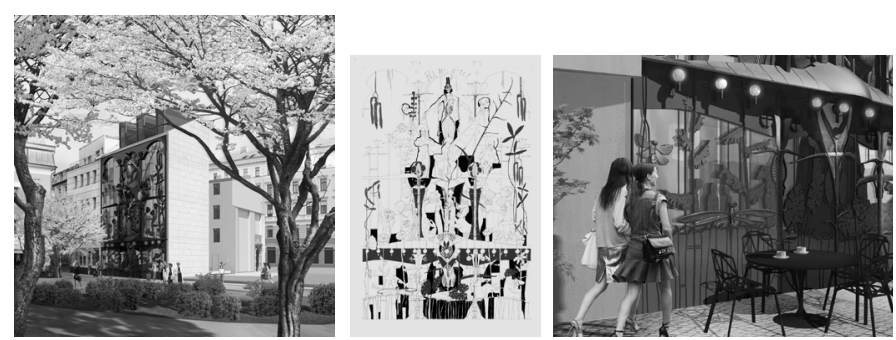

Fig. 28. Rīga. 47 Vaḷnu Street. "MARK”, Artist - R. Koḷcovs, 2012 [34].

Pictorial surface architecture is a style in which the envelope surfaces of a building are created using pictorial means. The origins of this style date back to the late 1960s, when attempts were made to raise the aesthetic quality of the environmental image, constructing the buildings in such a way that the parts of the building's façade and certain empty planes are artistically decorated. The façade surfaces in this style are created with pictorial features, wall paintings, elements of graffiti art and photography. Colours, halftones, contrasts and chiaroscuro are used to make the façade resemble "a painting". Artistic decorations of the firewall façade surfaces are typical examples.

A noteworthy innovative example or pictorial surface architecture is an apartment building at 17 Skolas Street. Finnish architect studio "JKMM" was the winner of the international competition in 2006. Their entry featured pictorial colour patches on the building's façade (Fig. 26).

Two examples that display features of pictorial architecture are the hotel development project in 2008 at 12 Audejju Street (Fig. 27) created in collaboration with artist Kristaps Ģelzis, and the project entry in the competition 2012 for the reconstruction of the hotel in Riga, 47 Valı,nu Street (Fig. 28); the artist Roberts

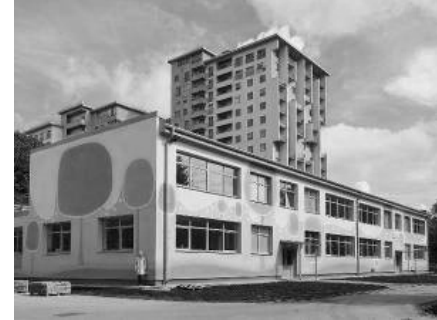

Fig. 29. Rīga. Kindergarten at 130 Slokas Street. Author of facade and interior - Līga Gaile. Photo - Riga City Council Property Department.

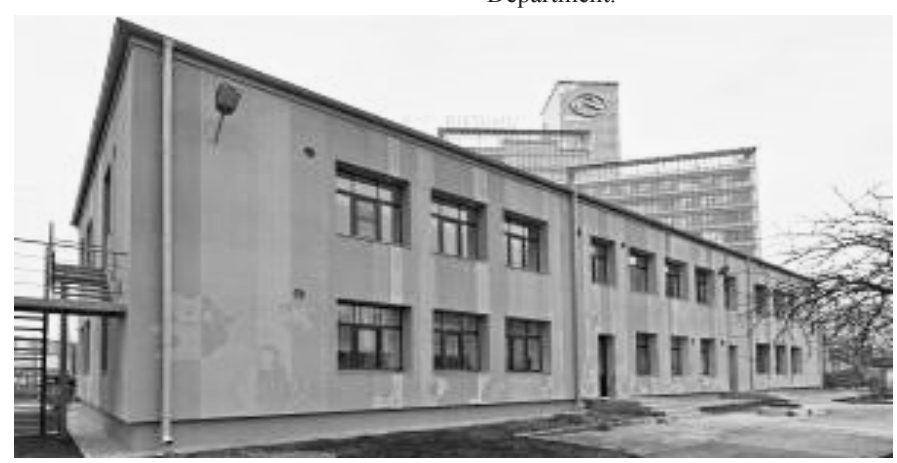

Fig. 31. Rīga. Kindergarten at 3 Grostonas Street. Author - Elīna Jonina, Supervisor - Ingūna Elere, 2014. Photo - Riga City Council Property Department.

Koḷcovs collaborated on the building's concept. Vaḷnu Street 47 competition project authors justify the cooperation with artist R. Koltsov: "The building is a message for every living being's natural desire to strive upwards - to the sun. The facade highlights the artist's vision of the world and eliminates the potential breakdown in any architectural style at the same time creating an unquestionable architectural space sign in the Old Town" [34].

The painting of facades in modern architecture is rather popular, as it is one of the most financially advantageous decorative means in reconstructing a building's façade. In 2014 a project to raise energy efficiency took place in which some kindergarten and school building facades underwent a conceptual reconstruction (Fig. 29-31). Façade recoating and painting projects were developed in cooperation with the students of Latvian Academy of Arts.

Time and again one can find sculptural and ornamental means of expression simultaneously present in the same building. This is called surface ornamental sculptural architecture. The most widely used materials in the finish of these buildings is printed, coloured, frosted or deformed glass as well as perforated metal and other materials. The form of the object is highlighted by the sculptural décor elements in the building's façade, thereby creating an impressive image. The features of this style in Latvia can be seen in the plastic finish of the Vidzeme Concert Hall facades (Fig. 32) and in the textual façade of Pārventa Library (Fig. 32), (Fig. 33).

Sometimes certain visual effects in surface architecture are achieved with finishing materials by attempting to resemble other materials, including textiles. This is done by highlighting the texture of a material and its physical properties. This 


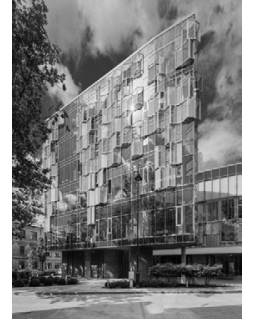

Fig. 32. Cēsis. Vidzeme Concert Hall. J. Poga, 2014 [35].
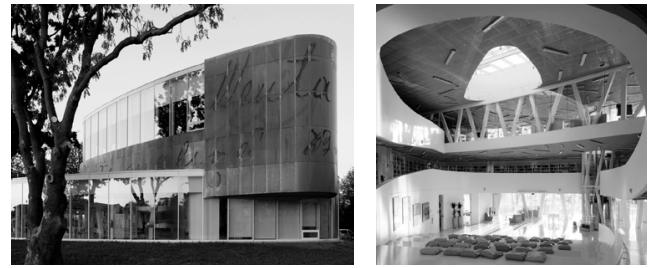

Fig. 33. Ventspils. Pārventa Library. "INDIA arhitekti", Competition 2006, realisation in 2009 [36].

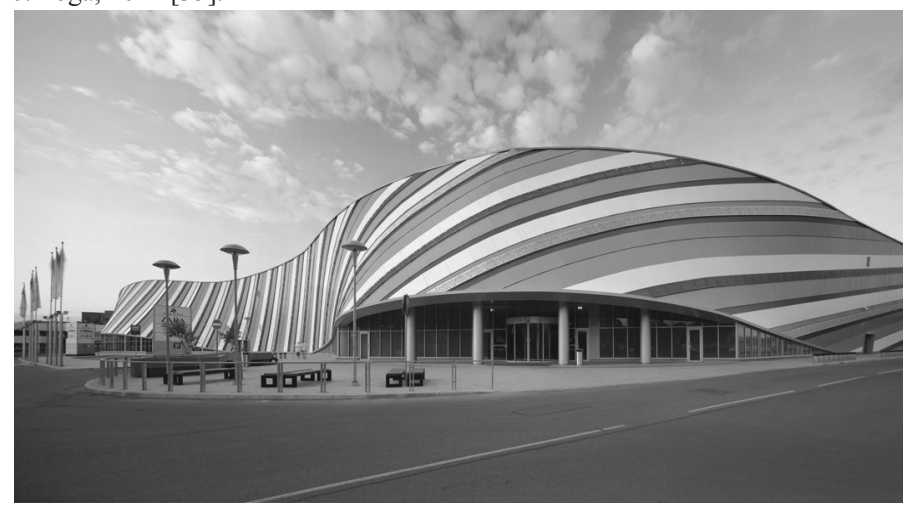

Fig. 34. Rīga. Shopping centre Riga Plaza. “ARHIS”, 2009 [38].

style is sometimes called Architextile [37]. This style is often mentioned in the World Wide Web in association with projects which are a result of collaboration of architects and fashion designers. Some acoustic textile products that have been made available by modern technologies can be used as wall finishes; they can be used as bulkheads or used to manufacture individual interior objects. These materials are "three-dimensional", as they have an embossed surface texture created by using patented weaving technology [37]. All this gives way to rather innovative effects, synthesizing the work of textile designers and architects. Architextile usually overlaps with sculptural ornamental surface architecture. The difference being in the accentuation - the former gives most of the attention to the materials and technological means in a building's finish.

Often one can find expressive objects in both Latvia and the world equally influenced by sculptural architecture and the ornamental style. This is called ornamental sculptural architecture and it features experimentation with form and ornamentation. This style can be witnessed in the work by "ARHIS", "8.A.M.", "NRJA", architect Ugis Šēnbergs and others (Fig. 34-39).

Ornamentally sculptural architectural example is the 2013 competition entry for New Riga Theatre reconstruction at Lāčplēša Street by architectural office "NRJA" under the title "Under the Skin". The architects proposed to connect the new building and the existing one into one volume using a sculptural roof the material of which was used for both the roof and walls thus emphasizing the unity of the shape. the project authors stated: "The skin also serves as a barrier that separates the theatre from the outside world. The texture of the skin is made of smooth, graphite-gray cement tiles. This also gives a modern interpretation of the brick firewall pattern" [43].

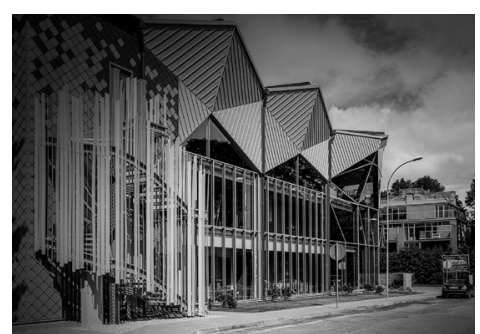

Fig. 35. Jūrmala. "Kurshi" hotel. "8.A.M.", 2014 [39].

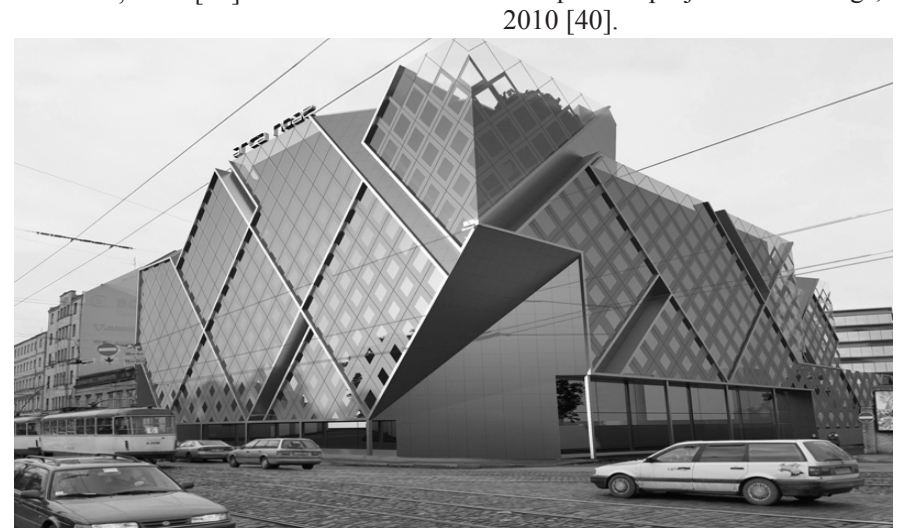

Fig. 37. Rīga. Multifunctional building. Sketch project. A. Kleinbergs, J. Zvejnieks, S .Ozola, K. Šulcs, 2009 [41].

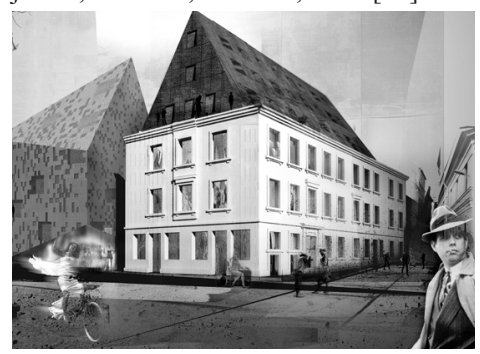

Fig. 38. Rīga. Apartment building at Kungu Street. Competition winner. U. Šēnbergs, 2007 [42].

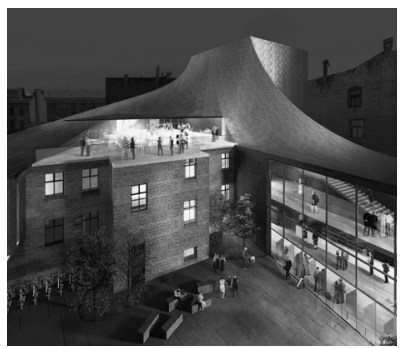

Fig. 39. Rīga. New Riga Theatre reconstruction. . Competition entry. "NRJA", 2013 [43].
The rapid development of modern technologies allows not only for the creation of different static objects but also physically moving buildings and moving parts. This style of architecture is called kinetic architecture [44]. The use of mechanics, robotics and electronics give way to a new chapter of development in architecture. The transformation of structures in kinetic architecture is possible in accordance with changes in climate, people's needs or to serve a decorative function. The amount of transformation can vary from individual elements in a building's façade to considerable changes in the façade, leading to changes in the building's dimensions. Depending on the level of transformational capacities in a building, in the context of the synthesis of arts, the styles of surface kinetic architecture and sculptural kinetic architecture can be distinguished.

There are few buildings featuring this style of architecture in Latvia. One of the examples is the bank "Citadele" building located at Republikas Square designed by architect Meinhard von Gerkan (Fig. 40). The building features saturated colours and kinetic shutters. The example of surface kinetic architecture was Latvia pavilion in Shanghai featured in EXPO 2010 (Fig. 41). The façade of the pavilion was decorated with coloured plastic plates which dynamically undulated under the wind exposure. 

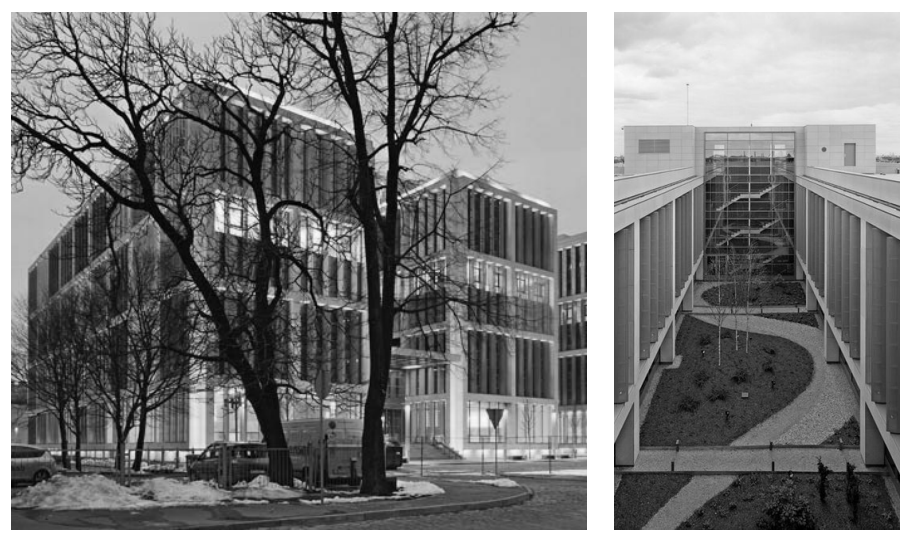

Fig. 40. Rīga. Administrative and office building "Citadele". M. fon Gerkan. Construction and details: "Vincents projektěšanas grupa", 2003-2009. [45]

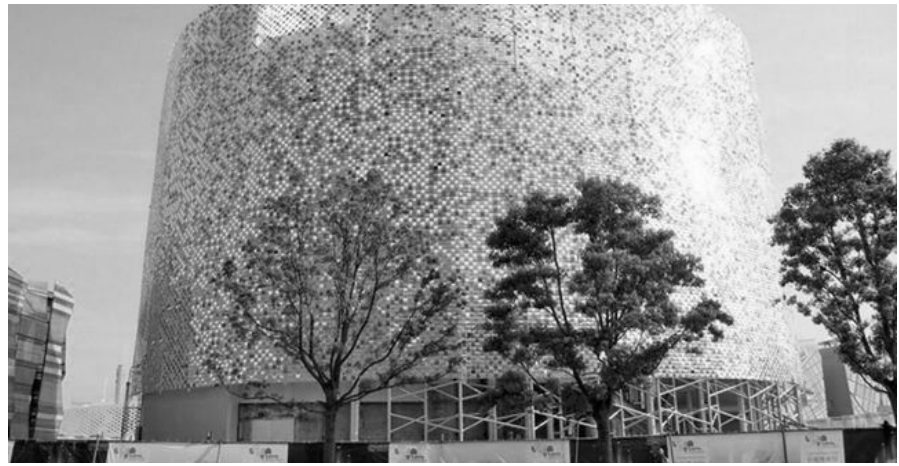

Fig. 41. China, Shanghai. Latvia pavilion at Expo 2010. "Mailitis A.I.I.M.", $2010[22]$.

A movable pavilion and a concert hall were designed for the multimedia education event "Dabas koncertzāle" in Sigulda (Fig. 42). There was enough space for an academic chamber orchestra and a group of musicians under the roof of the pavilion. Light shows and visual projections were projected on the walls of the pavilion. The construction of the object was made up of a system of modules, so its overall size and configuration could be changed with respect towards the nearby space and the environment. Another noteworthy example of kinetic architecture is the floating stage project on the river Salaca which provided mobile floating stage, according to the needs of various cultural events (Fig. 43) [46].

\section{CONCLUSION}

There have been a multitude of attempts at merging the arts in contemporary architecture, furthermore - some of the experimental objects prove to be highly innovative in respect to the artistic language being used, thereby - with respect to formal styles - creating new territory where contemporary architecture is considered. Traditional boundaries between architecture, the arts and other fields are being more and more dissolved. This has given way to an art form comprised of many arts where the architect serves the role of an interdisciplinary coordinator of processes. This type of architecture cannot be a mass product while striving for a unique identity it becomes very specific in its individuality; however ensuring the emotional experience akin to any work of art.
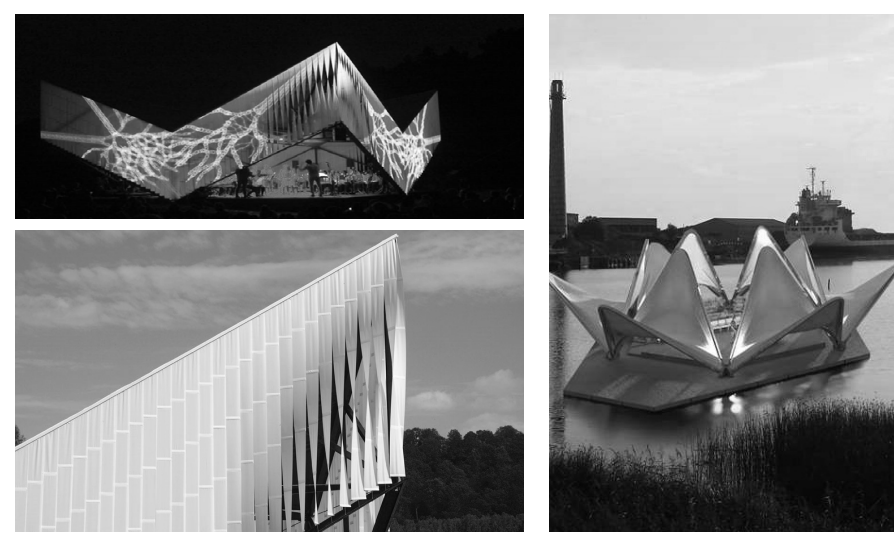

Fig. 42. Sigulda. "Dabas koncertzāle" pavilion. "DJA", D. Jaunzems, K. Pickaine, 2014 [47].
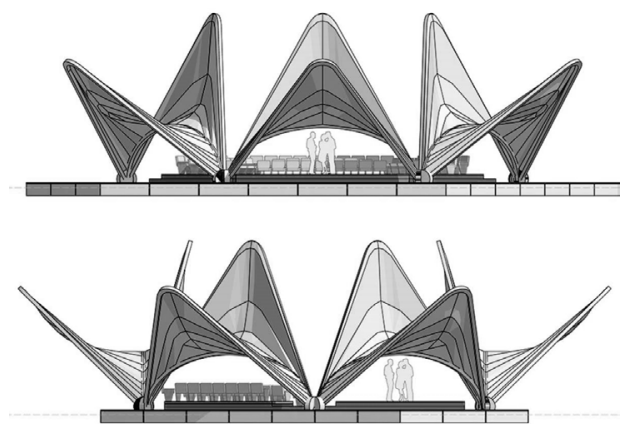

Fig. 43. Salacgrīva. Floating stage. Competition entry. E. Tokarevs, S. Lašins, $2011[47]$.

Laconically speaking "Artistic buildings in an artistic environment" can be a way of describing the ideological aspirations of the 21 st century which have led to the swift increase in popularity of the style of art architecture. In the modern era, society undergoes constant change with the passage of time and the pace of life increasing faster than ever. Therefore no individual style or art form can prevail over the others and can be practiced and refined over a longer period of time. Modern architecture does not conform very well to the classical system of style classification where every new emerging style attempted to disavow the previous. In the 21 st century this process can happen over a very short period of time - we can see the emergence, change or disappearance of different stylistic trends. Current events and every artist's individual style or "handwriting" become increasingly more decisive.

The leading formal styles of contemporary architecture in the 21 st century are sculptural architecture and surface architecture, surface architecture being the more widespread. While the creative methods used in the context of Latvia do not always amount to the variety and quality we can witness in the surface architecture of the world, some objects in the style of sculptural architecture, which is not very common in Latvia, display high architectural quality and attempt to explore this style. Until now, a synthesis of the arts in architecture has been attempted only in collaboration with the fine arts. Emerging in the late 20th century, different multimedia arts and kinetic technologies now play a significant role in how we understand the idea of a building and have become features of the artistic language and identity of contemporary architecture. 


\section{REFERENCES}

1. Krastiņ̌š, J., Strautmanis, I., Dripe, J. Latvijas arhitektūra no senatnes lìdz mūsdienām. Rīga: Baltika, 1998, 226.-237. lpp.

2. DALA artarchitecture for social change [online]. DALA [cited 15.07.2010.]. http://www.dala.org.za/

3. Jencks, Ch. The Iconic Building : The Power of Enigma. New York: Rizzoli, 2005. 223 p. ISBN 08478275699780847827565.

4. Zvirgzdin̄š, A. Arhitektūra kā māksla. Latvijas Arhitektūra, 2007, Nr. 6 (74), 14.-18. lpp.

5. Krastiňš, J. Arhitektūras stili Latvijā [tiešsaiste, skatīts 05.02.2015.] http://e.znet.lv/Arhitekt_stili_Latvija_Text.pdf

6. Sungur, E. ArhiSculpture : Dialogues between Architecture and Sculpture [online]. Dexigner [cited 13.07.2010.]. http//www.dexigner.com/architecture/news-g6570.html

7. Farrelly, L. The fundamentals of architecture. Lausanne: AVA Academia, 2007. 176 p. ISBN 9782940373482.

8. Kempe, I. Arhiskulptūra [tiešsaiste]. A4d Raksti [skatīts 18.12.2014.] http://www.a4d.lv/lv/raksti/427

9. Biroju ēka Kāpsalā, Matrožu ielā 15 [tiešsaiste]. Arhitektonika [skatīts 06.01.2014.]. http://www.arhitektonika.lv/?lang=lv

10. Collector coin for Rezekne city : CSC Zeimuls : COMPLETED [online]. SAALS [cited 02.02.2014.]. http://www.saals.lv/design/\#/collector-coin/

11. Latvijas Nacionālā bibliotēka [tiešsaiste]. a4d [skatīts 06.01.2014.]. http:// www.a4d.lv/lv/projekti/latvijas-nacionala-biblioteka/

12. Darījumu cents Ķ̄ipsalā. Latvijas Arhitektūra, 2002, Nr. 39, 92.-95. lpp.

13. Tāds Saules akmens [tiešsaiste]. a4d Raksti [skatīts 20.02.2015.]. http:// www.a4d.lv/lv/raksti/tads saules akmens/

14. 2009. gada notikumi. 2009. gada 29. decembris [tiešsaiste]. a4d [skatīts 20.02.2015.]. http://www.a4d.lv/lv/raksti/2009-gada-notikumi-latvija/

15. Holcmane, V. "Lielais Dzintars" Liepājā, Latvijas Arhitektūra, 2003, Nr. 50, 76.-77. lpp.

16. Kempe, I. Jaunais Liepājas koncertzāles projekta piedāvājums [tiešsaiste] a4d [skatīts 04.06.2015.]. http://www.a4d.lv/lv/projekti/377

17. Skārnu iela 11 [tiešsaiste]. Dekarta Property [skatīts 19.02.2015.]. http:// www.dpg.lv/lv/objekti/skarnu-11/

18. Sporta laukuma sezonu pagarinošs milzu jāņtārpiňš [tiešsaiste]. a4d [skatīts 06.01.2014.]. http://www.a4d.lv/lv/projekti/sporta_laukuma_sezonu pagarinoss milzu jantarpins/

19. Liepājas daudzfunkcionālais centrs „Lielais dzintars” [tiešsaiste]. Vegal [skatîts 18.02.2015.]. http://vega1.lv/project/liepajas-daudzfunkcionalais-centrs-lielais-dzintars/

20. Dziesmu svētku estrāde [tiešsaiste]. Rīgas meži [skatīts 19.02.2015.] http://www.rigasmezi.lv/lv/mezaparks/par_parku/dziesmu_svetku_estrade/?doc $=1167$

21. Mežaparka Lielā estrāde - žūrijas viedokḷi [tiešsaiste]. a4d [skatīts 19.02.2015.]. http://www.a4d.lv/lv/projekti/mezaparka_liela_estrade_zurijas viedokli/

22. Paviljons : Latvia Expo [tiešsaiste 23.02.2015.]. http://www.latviaexpo. com/lv/apmekletajiem/paviljons

23. AirBaltic Passenger Terminal. Haptic Architects [online]. Haptic [cited 19.02.2015.]. http://hapticarchitects.com/work/airbaltic-passenger-terminal-riga-latvia/

24. Pūt vējiṇi konkursa uzvarētāju projekts [tiešsaiste]. a4d [skatīts 19.02.2015.]. http://www.a4d.lv/lv/projekti/put-vejini-konkursa-uzvaretaju-projekts/

25. Rīgas Koncertzāles projekts - AB.SZK [tiešsaiste]. Dizaini [skatīts 18.02.2015.]. http://www.dizaini.lv/?p=3033

26. Dzintaru 32 / SZK/Z Architects [online]. ArchDaily [cited 23.02.2015.] http://www.archdaily.com/412023/dzintaru-32-ugis-zabers-szk/

27. Winning proposal - art nouveau meets green [online]. NRJA (No Rules Just Architecture) [skatīts 19.02.2015.] http://www.nrja.lv/index.php?id=187

28. Jaunais kultūrizglītības centrs Ādažos [tiešsaiste]. abc.lv [skatîts 02.02.2014.]. http://www.abc.lv/article/kulturizglitibas_centrs_adazos/

29. Housing : Dz̄ivojamā ēka Jūrmalā Sporta ielā [tiešsasite]. Uǵis Šēnbergs, arhitekts [skatīts 23.02.2015.]. http://www.senbergs.lv/eng/projects/index. php?5056
30. Sabiedriskais komplekss Jūrmalā - Balta istaba [tiešsaiste]. a $4 d$ [skatīts 18.04.2015]. http://www.a4d.lv/lv/projekti/sabiedriskais-komplekss-jurmala-balta-istaba/

31. Latvija. Ventspils : Ražošanas ēka Dzintaru ielā 3/5 : AKA birojs : 2006-2007 [tiešsaiste]. Kultūras karte [skatīts 10.01.2014.]. http://www. kulturaskarte.1v/lv/musdienu-arhitektura/sulu-koncentratu-parkrausanas-un-uzglabasanas-terminals-ventspili

32. Konkursi. Velve [tiešsaiste]. Velve : Velves nekustamie īpašumi [skatīts 18.02.2015.]. http://www.velveni.lv/lv/contest

33. Viesnīcas ēkas attīstības priekšlikums Audēju 12 [tiešsaiste]. SZK un Partneri [skatīts 18.04.2015]. http://p.szk.lv/projekti/viesnicas-ekas-buvniecibas-attistibas-priekslikums\#4

34. Viesnīca Vecrīgā [tiešsaiste]. MARK arhitekti [skatīts 18.04.2015.]. http:// mark.lv/lv/projekti/74

35. Cēsu koncertzāle [tiešsaiste]. a4d [skatīts 20.02.2015.]. http://www.a4d. lv/lv/projekti/cesu-koncertzale

36. Iepriekšējie laureāti : 2009. Pārventas bibliotēka Venstpilī [tiešsaiste]. Latvijas Arhitektūras gada balva [skatīts 07.01.2014.]. http://www.arhitektura2014.lv/laureati/

37. Architextile : Materialize the Future [online]. Materia [cited 13.07.2010.] http://www.materia.nl/575.0.html?\&user_material[material_uid] $=1342$

38. Riga Plaza : Arhis. [tiešsaiste]. Archdaily [cited13.10.2013.]. http://www. archdaily.com/166291/riga-plaza-arhis

39. Kurshi Hotel : Fotogalerija [tiešsaiste 31.03.2015.]. http://www.kurshihotel.lv/fotogalerija/

40. Konkurss „Marriott hotel Rīga”, fasādes [tiešsaiste]. Uǵis Šēnbergs, arhitekts [skatīts 22.11.2014.]. http://www.senbergs.lv/lat/projects/index. php?3066\&text

41. Daudzfunkcionāls ēku komplekss Rīgā starp Brīvības, Etnas un Mazā Klijānu ielām [tiešsaiste]. Arhis [skatīts 22.11.2014.]. http://www.arhis.lv/ index.php?action=product\&cat_id=22\&id $=220 .=$

42. Kungu, Kalēju, Peitavas - Uǵis Šēnbergs. Arhitekts [tiešsaiste]. a4d [skatīts 19.02.2015.]. http://www.a4d.lv/lv/projekti/kungu_kaleju_peitavas ugis senbergs arhitekts/

43. Jaunais Rīgas teātris. NRJA [tiešsaiste]. a4d [skatīts 19.02.2015.]. http:// www.a4d.lv/lv/projekti/jaunais-rigas-teatris-nrja/

44. Zuk, W. Kinetic architecture. New York : Van Nostrand Reinhold, 1970. $163 \mathrm{p}$.

45. Jaunā ēka Citadelē [tiešsaiste]. a4d [skatīts 06.01.2014.]. http://www.a4d. lv/lv/projekti/citadele-parex/

46. Tokarev, E. Float platform [online]. Architezer [cited 22.11.2014.]. http:// architizer.com/projects/float-platform/

47. Pavilion and Workshops for Nature Concery Hall : Sigulda, Latvia [online]. Architezer [cited 22.11.2014.]. http://architizer.com/projects/pavilion-and-workshops-for-nature-concert-hall/ 


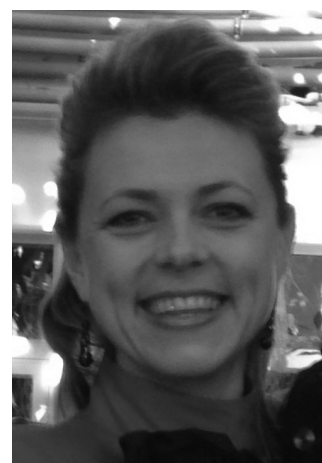

Ilze Rukmane-Poča, Dr. arch., received the Master degree in Engineering Sciences and Architecture in 2004 and $\mathrm{PhD}$ in Architecture in 2015 from Riga Technical University. From 1998 - 2007, she was an architect with the architect bureau "Postform Projekts Rīga" Ltd. Since 2007, she has been an architect - project manager with architect bureau "Balta istaba" Ltd. Since 2008, she is a Board member of the architect bureau "Balta istaba" Ltd. She is a certified architect. Since 2009, she is a lecturer in Architectural Design and Typology with the Faculty of Architecture and Urban Planning, Riga Technical University. She has participated in several international con-

ferences. Her research interests are synthesis of art and architecture, contemporary architecture of the 21 st century.

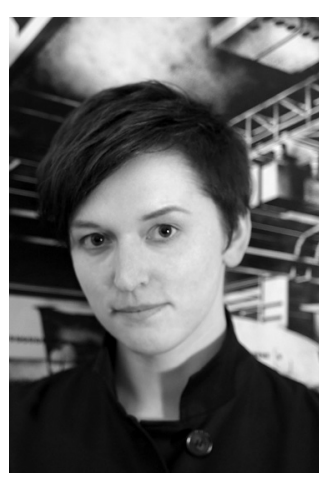

Linda Leitāne-Šmīdberga received B. arch.in 2004, M. Sc. arch. in 2007 and PhD from (Riga Technical University. Since 2008, she has been an architect with the architecture office "NRJA". As a member of different teams she has participated in more than 30 local and international architecture competitions. She has been a curator of Latvian national exposition in Venice Biennale and the 14th International Architecture Exhibition in 2014.

\section{CONTACT DATA}

Ilze Rukmane-Poča

Architect, Dr.arch.

22 Rūpniecības Str., Riga LV-1010, Latvia

Phone: +371 26334545; +37167323636

E-mail.: ilze@baltaistaba.lv; ilze.baltaistaba@inbox.lv

Linda Leitāne-Šmīdberga

NRJA Address: 12 Miesnieku Str., Riga, LV-1050, Latvia

Phone: +371 26552295

E-mail: leitane.linda@gmail.com www.arhkonkursi.lv 